International Research Journal of Management, IT \& Social Sciences
Available online at https://sloap.org/journals/index.php/irjmis/
Vol. 8 No. 1, January 2021, pages: 1-8
ISSN: 2395-7492
https://doi.org/10.21744/irjmis.v8n1.1041

\title{
The Application of Child Adoption (Balaku Anak) and Its Legal Effects on Customary Law System of the Dayak Ngaju Tribe
}

Rizki Yudha Bramantyo ${ }^{\mathrm{a}}$ Irham Rahman $^{\mathrm{b}}$

Article history:

Submitted: 18 September 2020

Revised: 09 October 2020

Accepted: 27 November 2020

\section{Keywords:}

child behavior;

customary law;

Dayak Ngaju;

Islamic law;

legal effects;

\section{Abstract}

The purpose of this research is to find out how the application of children's behavior and its influence on the customary law system of the Dayak Ngaju Tribe. The research method used is qualitative. Primary data comes from observations and interviews. Meanwhile, secondary data from previous studies were collected to support the findings. The findings reveal that there are differences in the rule of law between Islamic law and positive law and customary law of the Dayak Ngaju tribe. Islamic law regulates inheritance and inheritance rights according to lineage, positive law regulates the return of cases of adoption to civil law, and customary Dayak Ngaju law recognizes adoption.

International research journal of management, IT and social sciences (C) 2021. This is an open access article under the CC BY-NC-ND license (https://creativecommons.org/licenses/by-nc-nd/4.0/).

\section{Corresponding author:}

Rizki Yudha Bramantyo,

Faculty of Law, Kadiri University, Indonesia.

Email address: rizki_bramantyo@unik-kediri.ac.id

${ }^{a}$ Faculty of Law, Kadiri University, Indonesia

${ }^{\mathrm{b}}$ Faculty of Law, Kadiri University, Indonesia 


\section{Introduction}

Central Kalimantan is one of the provinces of the Republic of Indonesia, which is located on the island of Kalimantan. The local community or the original inhabitants are the Dayak tribe. The Dayak tribe itself is divided into several sub-tribes, which are many, including Dayak Ngaju, Manyan, Bakumpai, Ot-Danum, Ma'nyan, Ot-Siang, Lawangan, Katingan, and others. In some areas, there are still local Dayak tribes who still live with their respective local wisdom and their lives are still very traditional and simple, usually living on the coast of the river, as seen on the coast of the Barito river there are Dayak Ot-Olong, Dayak Penyawung, Ot-Paridan, and Ot-Saribas. Some of the latter sub-tribes still depend on nature and live closely with local wisdom (Mulyoutami et al., 2009).

Many government development programs have been implemented both in infrastructure development (roads and bridges) as well as development in other fields. This has had a significant impact and change in the economic, social, and cultural fields as well as the customs of the local community (Suwarno, 2017). Meanwhile, challenges in economic development are the deprivation of traditional Dayak land rights and environmental damage, destructive government policies, and globalization (Bamba, 2017).

However, the occurrence of social change cannot be prevented; the pace of the development of the era is accompanied by the pace of development, breaking through the forest, spreading asphalt into roads, opening easy access from one area to another, even in areas that were previously isolated. Open access roads make easy access to information and everything, including access to goods and services. The wheels could turn across it, no need for an outboard motor propeller, which was risky, slow, and a long way around the creek. With the opening of land access, new economic opportunities are starting to emerge. Shops, stalls, and stalls, restaurants, and so on. Realizing that land routes were easier to use and more promising buying and selling opportunities, created a change of profession. The change in the profession in question, from initially depending on the river, as a fisherman, as a Keramba farmer, as a seller of water transportation services, moved to land on the side of the road. Opening a river food shop, fried fish, grilled fish, and so on (Darmadi, 2017).

Social and economic changes are of course led by young people who go to school. Awareness of science and the importance of studying at a young age as a provision later in adulthood have made many of the young generations of the Dayak Ngaju Tribe in Pahandut District, Palangka Raya City start seriously studying and going to school and even studying outside the island up to the level of three strata or doctoral level. Prof. Eddy Leon, M.Pd, who is one of the key informants of this study, said that social change would move in line with the community educational background.

However, one thing is the culture and values of local wisdom that have not changed much, namely households. Family law will not be far from around marriage, adoption, divorce, and inheritance. Regarding married life, wise bestari, said advice is still and always given by the elders as provisions for the younger generation to live a happy household life until the end of time. Starting from the marriage system, kinship, most of the Dayak Ngaju people in Pahandut District, Palangka Raya City still applies the indigenous Dayak culture's noble values. The kinship system of the Dayak Ngaju people in the Pahandut sub-district of Palangka Raya City is based on the principle of ambilineal descent, which is a kinship system that takes into account the kinship relationship for some people in society through men and for some others, in that society too, through women (Darmadi, 2017; Widen, 2017).

Traditional ceremonies in Central Kalimantan are an inseparable link from Tattwa which is the core of the Hindu Kaharingan religious teachings (the original religious tradition of the Dayak people) with morals which are rules that should be implemented to achieve goals (Qalyubi, 2018). The elements of tattwa, ethics, and ceremonies are universal elements of Hindu Kaharingan teachings that are contained in every ritual carried out by the Dayak community, in which elements must be understood and obeyed in an integrated and simultaneous manner and inseparably (Jarias, 2020; Atok, 2020).

One expectation that is from the marriage event itself is the continuation of offspring or having children as the next generation of the family (Haug, 2017). However, as the wise words that fortune, mate, and death have been arranged by the Most Living, so also not all families are blessed with fertility and many children. Others have to be patient with not being given offspring. Even though children in the Ngaju family are proud, especially boys who are believed to be responsible for bringing the spirits of their father and mother to holiness through tiwah ceremonies and so on. Then how do the Ngaju people respond to this, customary law as a respected and obeyed ancestral heritage provides a solution for child balaku or adoption or child balaku. How does the customary law of the Dayak Ngaju tribe regulate this, are there legal consequences that arise, especially with inheritance and civil rights. 


\section{Materials and Methods}

This research was conducted in field or empirical research, which was analyzed using interactive data analysis methods (Bogdan et al., 1975). Data obtained by carrying out observations and in-depth interviews. Interview informants were selected based on their closeness to the problem under study, especially the perpetrators themselves, and were developed extensively with the purposive snowball sampling method of informant selection. The research result will be presented in a descriptive narrative in sequential, complete, and show location actual condition.

The residence of the Ngaju Dayak tribe which is the subject of this research is along with the large Kahayan river flow. In the great Kahayan River, Ngaju lives in the downstream area, while in the huku is inhabited by the Ot-Danum sub-tribe. The boundaries of the ngaju people go downstream, usually limited to the village of Tumbang Miri. If it is continued upstream, it will directly enter the Ot-Danum Sub-tribe (people) area. Research for Beginner Lecturers this time took the research area in the Banama Tingang District, Gunung Mas Regency, and Central Kalimantan Province. Due to the COVID-19 pandemic, which forced researchers to change the research method from the beginning by going directly to the research location, it was replaced by using media and technology.

\section{Results and Discussions}

\subsection{Balaku Anak in Dayak Ngaju Customary Law}

Balaku anak in the Ngaju language is called Balaku Anak, where balaku means beg or ask and a child means a child as the next generation. Based on the results of the field findings (the results of interviews with key informants Prof. Dr. Eddy Leon, M.Si and Dr. Netto W.S. Rahan) told the author that Balaku children in the indigenous Dayak Ngaju Tribe were carried out following customary rules such as,

\section{Disconnect with uluh bakas biological}

Break kinship with biological parents. Balaku children in the customary tatahum system of the Dayak Ngaju Tribe will completely sever the relationship between the child and his biological parents. Talks between adoptive parents and biological parents are held confidentially and adopted children should not find out. This is done to maintain harmony and balance in nature. So that life goes well.

\section{Adopted children become biological children of adopted families}

Adopted children will be considered the same as biological children. Large families of families who adopt children will be able to consider the adopted child as an appropriate biological child. Balaku Anak will be carried out in the custom order and rituals of the whole extended family will know about it and obey the agreements formed. To maintain harmony, the Ngaju Dayak Tribe will truly consider the adopted child to be their biological child. They will treat the adopted child as a real child. Uncle and aunt, grandfather, and grandmother did the same. It was as if the adopted child was a biological child. The child also feels the same affection, even biological children (if any) adopted siblings will treat the adopted child like siblings.

\section{Adopted children receive an inheritance from uluh bakas adopted according to the family agreement}

Underlining the rule that adopted children will be treated truly like real children, in the customary law system of the Dayak Ngaju people; adopted children will receive an inheritance and a will from the adopted family. This also ensures that the adopted child will not receive the same thing from his biological family. The child's text is completely cut off from his biological family.

\section{Balaku Anak Dayak Ngaju Customary Law System Do not correspond}

Based on the narrative of the key informant and supported by additional informants, to maintain harmony, balance, and sanctity of traditional ceremonies and rituals as well as to maintain brotherhood and kinship (avoiding accusations

Bramantyo, R. Y. ., \& Rahman, I. . (2020). The application of child adoption (balaku anak) and its legal effects on customary law system of the Dayak Ngaju tribe. International Research Journal of Management,

IT and Social Sciences, 8(1), 1-8. https://doi.org/10.21744/irjmis.v8n1.1041 
of distrust) and also never being taught by ancestors, Balaku, the son of the Dayak Ngaju tribe ever stated in any correspondence. In some families who are living modernly, adopted children are immediately registered on the family card as children. However, in many families who still adhere to customary laws and values strongly, the adopted child is just like that. Even so, nowadays all balaku children are usually directly entered into the Family Card, so the customary leader also acts as a social organizer of the community who will monitor the administrative order of the population of its citizens.

\subsection{The Balaku Model of the Ngaju Dayak Tribe}

In its implementation, there are several Balaku models for the Ngaju Dayak tribe. In general, it is almost similar to some of the other Dayak Sub-tribes. The model or form of child behavior that occurred was obtained from the results of observations and in-depth interviews with key informants at the research location (Bagner et al., 2010; Biederman et al., 1996). The models are,

\section{Balaku is a child because he does not have children}

One of the Dayak tribe in general or Ngaju is adopting children because the family is not or has not been blessed with offspring after being married for a long time. Balaku children are a solution to having children. The legal consequences of this child's Balaku will be discussed in the next chapter with the topic of the legal consequences of Balaku, the child of the Ngaju Dayak Tribe.

Balaku children, because they do not have offspring, are the simplest rule and have two traditional functions. The first is that the adopted child is intended to be the adoptive family child- The second is that the adopted child's presence is expected to be a provocation so that the family has a biological child. As a start so that the wife can get pregnant/pregnant. As explained by Prof. Dr. Eddy Leon, M.Pd, to the author closed to nuclear families only. This means that the adopted child cannot come from another family, especially from another tribe

\section{Balaku children because most children}

There was a family who lived simply by fishing and salting them and selling them. The family lives a simple and simple life, but the husband and wife are very fertile and are gifted with many children. Every year a child is born. The mother is so healthy the father is healthy. Even so, for the sake of the child's future, so that they can go to school and have a better future, some of the children are given to other families, who want to take care of the child and bear the responsibility for the child until the end of his life. Balaku children with this principle are recognized in the customary law system of the Dayak Ngaju tribe.

\section{Balaku children because children are sick in the family}

The next Balaku rule for children is the Balaku child which occurs when the child or the baby is continuously sick when cared for by the biological parents. As told by Dr. Netto Rahan, the child is not matched with his biological parents and the balance of the universe is disturbed. So one solution was tried, namely by adopting the child to another family who was still a relative. Try being raised by your mother's sister, being raised by your father's brother. When taken care of by a mother's or father's brother's sister, the child is healed and will be healthy forever. So it is considered that the child is matched with another family, and then for the sake of the child's health and life, the child is adopted by another household that is still a family.

\section{Balaku children happen because their birth parents suddenly passed away}

The kinship system of the indigenous Dayak Ngaju tribe has noble customary provisions. Prioritizing harmony and peace as an approach to solving all forms of social problems. Likewise in the maintenance of descendants and future generations. One form of Balaku children who are honored to the legal system of the indigenous Dayak Ngaju tribe is Balaku children whose parents suddenly died as a result of a natural disaster or accident. The abandoned child is the responsibility of his extended family, a large family meeting will soon be held to decide who the child is to care for. The Tampung Tawar ceremony will be held as a sacred part of a series of Balinese traditional Balinese ceremonies. 
Childhood behavior occurs because of dreams

The customs of the indigenous Dayak Ngaju tribe are still thick with nuances of spiritualism. The teachings of the ancestors and the nobility of customary norms that are still adhered to until now transform into a beautiful and extraordinary identity when examined from a social science point of view. One of the very interesting values is the occurrence of children's balaku that departs from the dreams seen by prospective adoptive parents. As told by Dr. Netto Rahan was also strengthened by Dr. Darsan, for example, a husband and wife who never had children, then saw in his dream that he could have a child, as long as he was hooked first by lifting a child from his brother. So based on this dream, the husband and wife consult with the traditional demang and then the child's Balaku is realized. Then two years after adopting a child, finally the husband and wife became pregnant and had offspring of their biological children.

Another story is another rule; there is also a husband and wife who dream of having to save a child who is sick in the care of their biological parents. After being complained to Demang, then demang with his spiritualism showed the sickly child. Long story short, the couple adopted the sick child and the child was able to recover and grow well and be healthy

\section{Child behavior to reconcile conflicts between families}

Huma Betang or rumah betang, which is a traditional house of the Dayak tribe, is a large and longhouse that is inhabited by several families who are still of one descent or kinship (Karliani et al., 2018). Then another betang containing another family and so on. Another function of the children's Balaku as a solution to social problems that arise in everyday life is an effort to reconcile disputing families (Suprayitno et al., 2019; Najman et al., 2000). For example, family A has a dispute with family B, so be reconciled by custom. Two solutions are offered, namely the heads of families A and B raise each other as adopted siblings, or the children of family A are adopted by B then the children of family B are adopted by family A. Thus families A and B are brothers with blood, inseparable.

\subsection{Balaku ceremony for the children of the Dayak Ngaju Tribe}

The results of the interview with the informant Mr. Offeny as an observer of Dayak culture, the researcher received information that the Balinese traditional ceremony of children has the concept of uniting people who are not bloodblooded, into flesh. Therefore, the Balaku ceremony for children has a high level of purity and sacredness. Some Dayak areas unite the blood of the prospective adoptive parents with the blood of the prospective adopted child in a container, combine them by stirring them, giving them a hardener that comes from rice, after joining them smeared on their faces accompanied by prayers and hopes that God Almighty will bless them.

\subsection{Legal consequences for the implementation of child Balaku}

Information obtained from in-depth interviews with Prof. Dr. Eddy Leon, M, Pd, that Dayak customary law does not recognize the differentiation of inheritance rights between boys and girls. Unlike the Javanese inheritance law which differentiates based on gender, and even differentiates based on birth order, anak mbarep-ragil children. Dayak customary law places inheritance rights to deliberation and consensus, all forms of parental inheritance are properly preserved and divided based on the results of extended family meetings. In ancient times when the Dayak tribe was still living in large betang-betang, a large family meeting was held to divide the inheritance rights, who held the family heirloom, how much of it was and that person was obliged to protect the family heirloom, usually in the form of mandau or pottery. Prof. Eddy said that usually, all inheritance assets were the same, except that there was a slight difference between children who took care of their parents until they died. Usually, the child is given more but everything returns to the extended family meeting. As a result of the law, traditionally the child who is being trained is no longer the son of the biological family. By customary law, the child broke his line and turned into a child from a family that bullied me (Polański, 2017; Joireman, 2008).

Especially for adopted children, as a result of the law or the consequences of the child's behavior, the child will no longer receive an inheritance from his biological parents, and he has the right to inherit from his adoptive parents. He will be considered as a real child and get affection from his siblings. Therefore, the balaku child must also be counted as part of the family meeting (Muzainah \& Faridh, 2019).

Bramantyo, R. Y. ., \& Rahman, I. . (2020). The application of child adoption (balaku anak) and its legal effects on customary law system of the Dayak Ngaju tribe. International Research Journal of Management,

IT and Social Sciences, 8(1), 1-8. https://doi.org/10.21744/irjmis.v8n1.1041 


\section{Discussion}

Recognition of habit into law according to state law (positive law), according to Austin, is defined as the law made by people or institutions that have sovereignty, and this recognition is enforced against members of an independent political society. These members of society recognize the sovereignty or supremacy of the person or law-making institutions concerned. Thus, according to him, habits will only act as law if the law requires or states explicitly the enforceability of these habits (Soemadiningrat, 2002).

The existence of a customary law community and its traditional rights is recognized by the State following Article 18 B paragraph (2) of the 1945 Constitution where recognition and respect are given without neglecting the feasibility measures for humanity following the level of development of the nation's existence. Such recognition and respect must not diminish the meaning of Indonesia as a country in the form of the unitary state of the Republic of Indonesia (Soemadiningrat, 2002). This provision gives recognition and respect to customary law communities which is a basic concept or pillar of customary law (Ashiddiqie, 2003).

If we refer to Islamic law, the Compilation of Islamic Law ("KHI") does not regulate adoption by single parents. KHI only explains the inheritance rights of adopted children. According to KHI, what is meant by adopted children are children who in terms of maintenance for their daily lives, education costs, and so on, shift their responsibility from their original parents to their adoptive parents based on a court decision (Article 171 letter h Islamic Law Compilation). The Indonesian Ulema Council ("MUI") has long been criticizing adoption. The fatwa became one of the results of the MUI National Working Meeting which took place in March 1984. In one point of consideration, the scholars viewed that Islam recognizes legal descent (nasab), namely children born from the marriage.

MUI reminded that when adopting (adopting) a child, do not let the child lose his lineage (nasab) with his biological father and mother. Because this is contrary to Islamic law. Many arguments underlie it, among others, the Al-Quran surah al-Ahzab verses $4-5$.

It is stated that the Prophet Muhammad SAW said that, "From Abu Dhar RA he heard Rasulullah say, "No one acknowledges (self-nationality) is not the real father, while he knows that it is not his father, but he has kufr (Bukhari) and Muslim)", in its fatwa, the MUI views that adopting a child should not necessarily change their status (nasab) and religion. For example, by pinning the name of the adoptive parent behind the child's name. Rasulullah has pointed out. Behind his name and do not necessarily change it to the name bin Muhammad.

Meanwhile, if viewed from the positive law in effect in Indonesia, adoption by a single parent is possible, provided that the single parent is an Indonesian citizen and has received permission from the Minister (Article 16 of Government Regulation No.54 of 2007 concerning Implementation of Appointment Child). Adoption of children by single parents is carried out through Child Care Institutions following the provisions of Article 10 paragraph (2) and paragraph (3) as well as Article 30 of the Regulation of the Minister of Social Affairs of the Republic of Indonesia Number 110/Huk/2009 of 2009 concerning the Requirements for Adoption of Children ("Permensos No. 110/2009”).

To be able to adopt a child through the Child Care Institution, the person must meet several requirements (Article 32 of the Minister of Social Affairs No. 110/2009) as follows: a. Physically and mentally healthy, both physically and mentally able to nurture CAA; b. Have a minimum age of 30 (thirty) years and a maximum of 55 (fifty-five) years; c. Religion is the same as the religion of the adopted child candidate; d. Have good character and have never been convicted of a crime; e. Do not or do not have children or only have one child; in a state of economic and social capacity; g. Obtaining children's consent, for children who have been able to convey their opinions and written permission from the child's parents/guardians; $h$. Make a written statement that adoption is in the best interests of the child, the welfare and protection of the child; i. The existence of social reports from the Provincial Social Agency Social Workers; $\mathrm{j}$. has cared for a prospective adopted child for at least 6 (six) months since the care permit was granted; and k. Obtaining a license to adopt children from the Minister of Social Affairs to be determined in court (Yasmin, 2016).

Thus according to Islamic law, adoption or adoption of a child may not break the lineage of the child with the biological parents; it is just that the child care is transferred to the adoptive parents. Here there is a fundamental difference where the Dayak Customary law completely cuts off the blood relationship of the child with the biological parents to be replaced with a new blood relationship with the parent or adoptive family in the widest possible scope including siblings, in the local tongue the term is a neighbor (serumah betang including aunts and so on). Meanwhile, according to the positive law in effect in Indonesia, adoption does not regulate blood or lineage ties (Jarias, 2020). Then the civil element applies in this case and the rights of the child towards their parents including the inheritance will return to the choice of law taken by the family and the parties involved (adoptive parents, adopted children, adopted siblings) apply the pacta sunt servanda principle where the family agreement that is reached on the issue is binding on 
the parties like a law. Disputes that may arise in the future will be settled amicably by the extended family or settled legally in the local district court according to the legal domicile of the parties following SEMA No. 2 of 1979 jo SEMA No. 6 of 1983 and also Government Regulation no. 54 of 2007 concerning the Implementation of Adoption of Children. The usual procedure in force at the Religious Courts before the birth of Law No. 3 of 2006, in filing a child adoption case, the prospective adoptive parents filed a case requesting adoption as is usually a volunteer case (application). In the Religious Courts, it is processed following the applicable procedural law until a Religious Court Decision is issued. As a reference in the examination procedure and the form of determination of the adoption application, it is usually guided by SEMA No. 2 of 1979 jo SEMA No. 6 of 1983. Adoption of children according to general civil law, before a case is submitted to the District Court, prospective adoptive parents must first obtain a license to adopt a child (adoption) from the Head of the Provincial Social Welfare Service. To obtain permission from the Head of the Provincial Social Welfare Service, prospective adoptive parents, and adopted children have met the requirements as stipulated in the Decree of the Minister of Social RI No.13/HUK/1993.

\section{Conclusion}

The findings of this study are that there are differences in the legal principles of Islamic law, positive law, and customary law of the Dayak Ngaju Tribe. Where it is related to blood relations and kinship, especially the Dayak Ngaju customary law will cut off kinship with the biological parents to be replaced by adoptive parents. This child also seems to be the biological child of an adopted family. Use the name of the adoptive father or foster family if any, etc., as if the adopted child is not an adopted child but a biological child. Meanwhile, under SEMA, Indonesia's positive law regulates the return of cases of adoption to civil law in general.

The customary laws of the Ngaju Dayak tribe, especially regarding adoption or Balaku Anak, are still firmly held today. The high level of education, the high level of welfare did not change their belief in the teachings of these ancestors. As obtained through observations and interviews, Prof. key informants. Dr. Eddy Leon, M.Pd himself is a child perpetrator where his youngest daughter is a balaku or adopted child. Even though he is highly educated, has a modern mindset, and is widely associated as a Professor at Palangka Raya University. Rather than that, he still adheres to the teachings of his customary law and enforces all his customary rules regarding the Balaku Anak. Likewise, as stated by Dr. Netto WS Rahan, Dr. Abdurrahman, Dr. John Rette are all informants of this research, serving as lecturers at Palangka Raya University. Demang Darsan, Demang Ugi from the research location who gave a direct account of the behavior values of children in the Dayak Tribe.

Balaku anak in the customary law system of the Dayak Ngaju tribe is a mechanism for solving social problems. The nuance is sacred, holy, full of life symbols and signs, and oriented to the peace and balance of the universe in the daily life and interactions of the Dayak people. In its implementation, there is no need to interfere with other legal systems, including national laws related to population administration or court decisions. This customary law is also referred to as a social solution to problems that arise in everyday social life, especially in terms of perpetuating generations or generations.

\section{Conflict of interest statement}

The authors declared that they have no competing interests.

\section{Statement of authorship}

The authors have a responsibility for the conception and design of the study. The authors have approved the final article.

\section{Acknowledgments}

We are grateful to two anonymous reviewers for their valuable comments on the earlier version of this paper.

Bramantyo, R. Y. ., \& Rahman, I. . (2020). The application of child adoption (balaku anak) and its legal effects on customary law system of the Dayak Ngaju tribe. International Research Journal of Management, 


\section{References}

Asshiddiqie, J. (2003). Konsolidasi naskah UUD 1945 setelah perubahan ke empat. Yarsif Watampone.

Atok, K. (2020). Gawai Dayak as Communication Media of Dayak People in Borneo. MEDIO, 2(1), 26-36.

Bagner, D. M., Pettit, J. W., Lewinsohn, P. M., \& Seeley, J. R. (2010). Effect of maternal depression on child behavior: a sensitive period?. Journal of the American Academy of Child \& Adolescent Psychiatry, 49(7), 699-707. https://doi.org/10.1016/j.jaac.2010.03.012

Bamba, J. (2017). Institut Dayakologi: The Challenges of an Information and Advocacy Centre of Dayak Culture in Kalimantan. In Borneo Studies in History, Society and Culture (pp. 313-340). Springer, Singapore.

Biederman, J., Faraone, S., Mick, E., Moore, P., \& Lelon, E. (1996). Child Behavior Checklist findings further support comorbidity between ADHD and major depression in a referred sample. Journal of the American Academy of Child \& Adolescent Psychiatry, 35(6), 734-742. https://doi.org/10.1097/00004583-199606000-00013

Bogdan, R., Taylor, S. J., \& Taylor, S. S. (1975). Introduction to qualitative research methods: A phenomenological approach to the social sciences. Wiley-Interscience.

Darmadi, H. (2017). Dayak and their daily life. Journal of Education, Teaching and Learning, 2(1), 42-46.

Haug, M. (2017). Men, women, and environmental change in Indonesia: the gendered face of development among the Dayak Benuaq. Austrian Journal of South-East Asian Studies, 10(1), 29-46.

Jarias, S. (2020). Values of Betang Culture as One of the Models in Realizing Better Life in Indonesia. International Journal of Management, 11(4).

Joireman, S. F. (2008). The mystery of capital formation in Sub-Saharan Africa: women, property rights and customary law. World Development, 36(7), 1233-1246. https://doi.org/10.1016/j.worlddev.2007.06.017

Karliani, E., Lion, E., \& Sakman, S. (2018, November). Huma Betang Philosophy as the Solidarity Prototype and Ethnic Conflict Prevention in Dayak Communities of Central Kalimantan. In Annual Civic Education Conference (ACEC 2018). Atlantis Press.

Mulyoutami, E., Rismawan, R., \& Joshi, L. (2009). Local knowledge and management of simpukng (forest gardens) among the Dayak people in East Kalimantan, Indonesia. Forest Ecology and Management, 257(10), 2054-2061. https://doi.org/10.1016/j.foreco.2009.01.042

Muzainah, G., \& Faridh, M. (2019). Customary Inheritance Law Acculturation On The Meratus Dayak Community. Development And Social Harmony In Southeast Asia (ICDIS) 2019, 14.

Najman, J. M., Williams, G. M., Nikles, J., Spence, S. U. E., Bor, W., O'CALlAGHAN, M. I. C. H. A. E. L., ... \& Andersen, M. J. (2000). Mothers' mental illness and child behavior problems: cause-effect association or observation bias?. Journal of the American Academy of Child \& Adolescent Psychiatry, 39(5), 592-602. https://doi.org/10.1097/00004583-200005000-00013

Polański, P. P. (2017). Cyberspace: A new branch of international customary law?. Computer law \& security review, 33(3), 371-381. https://doi.org/10.1016/j.clsr.2017.03.007

Qalyubi, I. (2018, July). The Duality Conception on Ngaju Dayak Thoughts in Central Kalimantan. In 2018 3rd International Conference on Education, Sports, Arts and Management Engineering (ICESAME 2018) (pp. 5-7). Atlantis Press.

Soemadiningrat, O. S. (2002). Rekonseptualisasi hukum adat kontemporer. Bandung: Alumni.

Suprayitno, S., Triyani, T., \& Pratiwi, P. F. P. (2019). Strategy on the National Unity and Politics Agency (KESBANGPOL) in Maintaining Ethnicity and Religious Relations Based on Huma Betang Philosophy in Central Kalimantan. Budapest International Research and Critics Institute (BIRCI-Journal): Humanities and Social Sciences, 2(4), 229-238.

Suwarno, S. (2017). Budaya huma betang masyarakat dayak kalimantan tengah dalam globalisasi: telaah konstruksi sosial. LINGUA: Jurnal Bahasa, Sastra, dan Pengajarannya, 14(1), 89-102.

Widen, K. (2017). The rise of Dayak identities in Central Kalimantan. In Borneo Studies in History, Society and Culture (pp. 273-282). Springer, Singapore.

Yasmin, M. (2016). Legal liability in standard form of contract. International research journal of engineering, IT \& scientific research, 2(9), 51-58. 